\title{
Applied Linguistics in Nepalese Academia: Historical Development, Contemporary Trends and Perspectives 1
}

\author{
- Bal Ram Adhikari \\ Lecturer, Mahendra Ratna Campus Tahachal
}

\begin{abstract}
Theoretical in its orientation, this article briefly surveys the historical development of applied linguistics, and its contemporary trends and perspectives in Western academia. Against this backdrop, it sheds light on the present situation of the discipline in Nepalese academia whereby its presence as an independent field of inquiry is yet to be realized. The article shows how the practice of applied linguistics in Nepal is confined to 'linguistics applied' and how the field has been subservient to linguistics and language teaching. Finally, it appeals for the practice of applied linguistics rather than merely linguistics applied in line with post-realities such as post-structuralism so as to address the language-related issues in the Nepalese society.
\end{abstract}

Keywords/terms: Linguistics, applied linguistics, critical applied linguistics, linguistics applied

\section{Introduction}

There has been a widespread tendency in Nepalese academia to take for granted the classical definition of linguistics "as the scientific study of

1 This article is the revised and extended version of a paper entitled Where Does Applied Linguistics Truly Lie in the Architecture of Nepalese Academia? Resituating the Discipline for the Welfare of the Society, jointly presented for a talk by Sajan Kumar Karn and Bal Ram Adhikari at the opening seminar of Nepalese Association for Applied Linguistics at CEDA Hall, TU, Kirtipur on $14^{\text {th }}$ September, 2013. I am deeply indebted to my co-presenter Sajan Kumar for granting the written permission to revise, extend and publish the paper in the form of an article. Also my special thanks to anonymous reviewers and the editorial team for their constructive feedback. The initial draft of the paper is also available on https://naaldiscourse. wordpress.com/. 
natural language" (Webster, 2003, p. vii) and to overlook social dimensions of the discipline. We have been repeating this definition in our classrooms for years and consequently our students have also been committing the same to their memory and reproducing in the exams.

We are living in the postmodern era, which is characterized by subjectivity, fluidity, plurality, ambiguity and uncertainty. And in this era, it is perhaps not wise to overemphasize the scientific nature of any discipline, including linguistics, at the expense of its relevance in human life and society. Particularly, the overemphasis on the 'scientificness of linguistics' that unduly calls for objectivity, certainty, abstraction, rationalization, and value-free nature of method and knowledge (Lyons, 1971 and 2002) has to be revisited for two main reasons. First, is science itself scientific in the truest sense of the word? This is the question raised and answered in the negation by many scientists in the West. For instance, Heisenberg's Uncertainty principle in science (Doren,1991), and Capra's (1976) notion of New Physics give equal status to rational knowledge generated by theory and intuitive insights garnered from practice. Similarly, our age has witnessed, Doren argues, "the fundamental; the underlying of all science at stake" (1991, pp. 337-38). This disturbing fact about human knowledge and the human effort to know has to be duly considered. Second, can the monolithic interpretation of linguistics do justice to the immensely complex and creative, and mysterious and multifaceted phenomenon like human language, whose roots spread from human psyche to society, from the rational to the (sub)conscious, from past to present? The nature of language transcends linguistic boundaries, because language is more than linguistics as echoed in the definition given by the British cultural critic Williams in these words: "The definition of language is always, implicitly or explicitly a definition of human beings in the world" (1977, p. 1). This is to argue that linguistics, in the name of 'scientificness', cannot and should not be dissociated from humanity, which in itself is full of infiniteness and mysteries.

The subject matter for linguistics is language which is, without any doubt, a social phenomenon. Truly, linguistics is a social science. Unfortunately, this social aspect of the discipline is often pushed to the periphery and scientific embellishment is brought to the fore. Upon scrutiny, the scientific facade has put the discipline and professionals both into trouble. Reasonably, a discipline has little chance of survival and growth unless it is relevant to society and attempts to alleviate people from their pains-sufferings. In this respect, Subedi posits that "personal experience and self-story telling is possible within linguistic studies which means linguistic studies is a highly 
humanized subject" (2007, p. 33). It is therefore to envision or propose the 'therapeutic role' of linguistics. Unfortunately, Nepalese society has gained little from this discipline though it has been a part of Nepalese academia for long. The scientific aroma of linguistics seems to have turned the discipline of linguistics more formal and therefore more mechanical. For many, linguistics has still remained merely a matter of morphological, syntactic and computational analysis. They hardly consider the social value and interdisciplinary nature of linguistics with due gravity.

Although the present article is more concerned with applied linguistics rather than general or theoretical linguistics, the interpretation of linguistics is bound to influence our interpretation of applied linguistics. In this connection, it would be worthwhile to read what Lier (1997) argues:

I think that it is the applied linguist who works with language in the real world, who is most likely to have a realistic picture of what language is, and not the theoretical linguist who sifts through several layers of idealization. Furthermore, it may well be the applied linguist who will most advance human kinds' understanding of language, provided that he or she is aware that no one has a monopoly on the definitions and conduct of science, theory, language research and truth. (as cited in Kaplan, 2002, p. 6)

Lier's assumption reveals the importance of doing applied linguistics over sifting through the layers of idealization. Indeed, Chomsky's interpretation of language led linguistics towards the analysis of I-language (idealized or internalized language) but in the last thirty or forty years linguistics has moved closer towards reality i.e. E-language (externalized or experienced language). Widdowson has rightly pointed out that "linguistics is now apparently coming to terms with reality: it now deals not only with what people know about language but also with what people do with it in their everyday contextualized dealings" (2001, p. 3). These interpretations reveal the benefits of doing applied linguistics on the one hand and how the dichotomy between linguistics and applied linguistics has ruptured in recent years (See Sridhar, 1993; Widdowson, 2001) on the other. Further, this has directed scholars' attention more towards the study of language-implicated issues in the real world (Cook, 2003).

The article raises and partly answers some key questions pertaining to the issues of applied linguistics such as- when and how did we begin? Have we moved hand in hand with the global trends in applied linguistics? Are we 
doing linguistics, linguistics applied, applied linguistics, critical applied linguistics or hypocritical applied linguistics? What are the ways we can resituate the discipline for its therapeutic value?

\section{When and how: Practice of applied linguistics is older than 'applied linguistics'}

Applied linguistics is not new in Nepal. Arguably, activities of applied linguistics began with the teaching of English in Nepal almost 160 years ago. By claiming this, however, we are perhaps ignoring the informal history of language teaching. In Nepal Sanskrit was taught and learnt informally even before that time. But then the term 'applied linguistics' had not even been conceived. It was only with the publication of the journal Language Learning in 1948 in North America (Allwright, 1998) that the term was first brought to the public. In this sense, we were doing applied linguistics before the term applied linguistics came into existence. Languages have been taught and learnt in the world since time immemorial; and there is dearth of literature on exactly when language teaching began. Historically, the beginning of language teaching should mark the beginning of applied linguistics. According to Schmitt and Celce-Murcia (2002), the development of applied linguistics (language teaching) can be traced back to ancient Greek; and the contribution of Plato and Aristotle can hardly be exaggerated in the design of a curriculum on grammar, writing and discourse (rhetoric). This, however, would be an incomplete interpretation of the history of applied linguistics. The whole world knows that Panini's Astadhyai, the first grammar in the history of language teaching, appeared in the $4^{\text {th }}$ century B.C. The contribution of Astadhyai in the teaching of Sanskrit and other oriental languages is beyond question. This gives us a ground to trace some applied linguistics in the $4^{\text {th }}$ century B.C. (Rajagopalan, 2004). It is only with the use of the term 'applied linguistics' in the late 1940s in the West that the scattered knowledge of applied linguistics got accumulated and its study became more systematized; its areas of explorations got widened, and it has become one of the most vibrant and burgeoning disciplines of the twenty first century. In this regard, we are in a position to argue that the practice of applied linguistics is older than the term 'applied linguistics'.

In the beginning, applied linguistics was "principally identified with the teaching of English as a foreign or second language" (Allwright, 1998, p. 9). The term was also interpreted as the application of linguistics in the field of language teaching. Recognizing applied linguistics as an activity, Corder (1973) interpreted it as the application of linguistic knowledge to some 
language-related areas. Thus the traditional interpretation treated applied linguists as the consumers of theories produced by linguists, not the producers of their own theories. This subaltern nature of dependence will be further interpreted in the section to come. Again, one thread related to the history of applied linguistics is worth presenting here. Kaplan explores into the history of the term in this way:

The term applied linguistics came into existence in the 1940s through the efforts of language teachers who wished to ally themselves with 'scientific' linguists and to disassociate themselves from teachers of literature. By the mid 1950s, the term was given credence by opening a school of applied linguistics at the University of Edinburgh (1956) and the creation of the Centre for the Applied Linguistics (CAL) in 1959 in the United States. Soon thereafter, during the 1960s, the term was institutionalized in the International Association of Applied Linguistics (AILA) in 1964 and in evolution of the series of national associations of applied linguistics, such as the British Association of Applied Linguistics in 1967. (2002, p. vii)

At this juncture, it is important that we look back in retrospect and see how the study of language began in Nepal. It is claimed that linguistics was formally introduced in Nepal by Professor Alan Davies. Tuladhar traces the genesis of linguistics and its teaching in Nepal in these words:

It is Professor Davies who first time introduced linguistics at the department of English, Tribhuvan University in 1969 when he was in the Chair twenty-four years ago and also ran three short-term courses on linguistics and applied linguistics for college teachers of English. He paved the way for linguistic studies in our university. In 1972 the Institute of Nepal and Asian Studies in cooperation with the Summer Institute of Linguistics launched an MA in Linguistics for the postgraduate in English. This was the first and last programme. (1994, p. 51)

It shows that seeds of linguistics and applied linguistics both were sown in Nepalese academia concomitantly. In the course of time, linguistics flourished but applied linguistics as a separate discipline did not even sprout. Later, Linguistic Society of Nepal was established in 1979, and Central Department of Linguistics in 1997 under the Faculty of Humanities and Social Sciences. As a result, linguistics has emerged as a securely firmed discipline in Nepal with its own professional society, a separate department 
and annual journals. Applied linguistics has been subsumed under linguistics, and some applied linguistic activities have taken place within Linguistic Society of Nepal and Department of Linguistics, which are commendable but not adequate.

\section{Applied linguistics: From technique to discipline}

Applied linguistics is one of the burgeoning disciplines in the global academia. The discipline that began with language teaching as the primary area of exploration has grown as a hydra in Greek mythology. This is because, whereas a number of new areas of explorations keep entering this discipline, other old areas are themselves growing as separate and independent disciplines; some of them are even disappearing or merging into another. However, applied linguistics is well and alive. At this juncture, referencing Grabe (2002, pp. 5-8), we can present briefly how applied linguistics has grown since the 1940s.

- In the 1950s, applied linguistics turned to structural and functional linguistics for theoretical insights that could be applied directly to second language teaching.

- In the 1960s, the field of applied linguistics embraced the areas such as language assessment, language policies, and second language acquisition (SLA). With this, it expanded its areas of investigation and the field gradually emerged as a genuine problem-exploring and problem-solving enterprise.

- In the 1970s, applied linguistics incorporated other areas such as multilingualism, language minority rights, language planning and policies, and teacher training, keeping language teaching at its heart. Now the field broadened in terms of its orientation, coverage and methods.

- In the decade of the 1980s, the field expanded further to encompass the subfields such as language use in professional settings, translation, lexicography, language and technology, and corpus linguistics. In fact, applied linguistics grew more as an interdisciplinary discipline as it continued to draw on, in addition to linguistics, many supporting disciplines such as psychology, education, anthropology, sociology, political science, policy studies, public administration, English studies, etc.

- Coming to the 1990s, applied linguistics emphasized: a) research in language teaching and teacher education with its prime focus on 
'teacher as a researcher' approach through action research; b) critical studies such as critical pedagogy, critical assessment, critical discourse analysis, and critical assessment practices; c) language use in academic, disciplinary and professional settings, and analysis of language in such settings; d) the possible applications of discourse analyses in corpus linguistics, register variation and genre variation; e) multilingualism and bilingualism; and f) the role of applied linguistics as a mediating discipline.

This expansion sheds light on how diverse and open-ended applied linguistics has grown in recent years. The plurality in applied linguistics makes Sridhar (1993) entitle his paper What are applied linguistics? instead of What is applied linguistics? whereby he discusses various conceptualizations and alternate paradigms related to the field. Applied linguistics in the plural has evolved as "a house of many rooms", to use Neubert and Shreve's (1992) metaphor, and the rooms in this house are different disciplines themselves and perspectives that are connected by a common subject, i.e. "knowledge about language and its relation to decision making in the real world" (Cook, 2002, p. 7). Owing to its infiniteness and open door policy, Rampton aptly characterizes applied linguistics as an open field of interest in language (1997, p.14); and Pennycook (2004) goes even a step further and argues that applied linguistics is "a way of thinking". What makes this field of inquiry so vibrant, dynamic and enduring? The answer is its osmotic capacity that can absorb the principles, methods, findings and even general insights from other neighboring disciplines and adapt to the changing needs of linguistically constructed human life.

Drawing on their theoretical convictions, practical goals and working experiences, different scholars have proposed different conceptualizations of applied linguistics. Some of the contemporary trends of conceptualizations are: applied linguistics as an academic discipline, applied linguistics as a problem-oriented discipline, applied linguistics as an interdisciplinary or multidimensional or even cross-disciplinary area, applied linguistics as a professional discourse, and so forth. Nevertheless, the most important point is Pennycook's (2004) rubric of 'critical applied linguistics'.

Critical applied linguistics can be interpreted as a postmodern approach to the study of language and linguistics. The postmodern paradigm in linguistics abandons grand narratives (Lyotard, 1984) altogether and relocates the impetus for action within the problem itself. It is only after the 1980s that critical perspectives made their entry into applied linguistics with the domains such as critical discourse analysis, critical pedagogy, critical literacy, critical language 
testing, critical approaches to language planning, language rights, translation and several others. Here, being critical does not merely mean a critique of the previous work but "to be critical means the appraisal of alternative versions of reality, the recognition of competing claims and perspectives, and the need to reconcile them" (Widdowson, 2001, p. 15). Along the same line, Pennycook views critical applied linguistics not merely as a critique of mainstream applied linguistics but also as "a way of exploring language in social contexts that goes beyond mere correlations between language and society, and instead raises more critical questions to do with access, power, disparity, desire, difference, and resistance" (2004, p. 797). Basing on critical theories, Pennycook considers applied linguistics as "an approach to language related questions that springs from an assumption that we live amid a world of pain, and that applied linguistics may have an important role in either the production or the alleviation of that pain" (ibid., p. 797-798). In a nutshell, the field that was conceived only as a set of techniques at its outset and that had to parasitically rely on linguistics as a parent discipline is now burgeoning in multiple forms and shapes.

\section{Are we doing applied linguistics or linguistics applied?}

Overall, we can discern two categories of people involved with applied linguistics. People of the first category teach applied linguistics as a subject in universities, so they are teachers of applied linguistics. The second category of people study applied linguistics so as to get through the exams, they are students of applied linguistics. Is applied linguistics merely teaching and learning of applied linguistics? The answer is No. To do so is to disregard the multifarious forms and functions of applied linguistics. Let us touch on the presence of applied linguistics in the curricula under Faculty of Humanities and Social Sciences, and Faculty of Education, Tribhubhan University, the oldest and the largest academic platform of the nation.

The University has not yet recognized applied linguistics as an independent field of teaching, training and researching. As a result, applied linguistics has remained an appendage to language teaching, pure linguistics and literature. There is a separate department of linguistics under the Faculty of Humanities and Social Sciences, established nearly two and a half decades ago with the aim of imparting "in-depth knowledge of linguistics and its practical applications in the Nepalese context" (http://cdltu.edu.np). It seems that applied linguistics has been understood as the practical aspect of theoretical linguistics and hence subsumed under linguistics accordingly. By this, applied linguistics has been conceptualized and actualized as the branch of linguistics. Likewise, the present curricula of Department of English Education and 
Nepali Education both have treated applied linguistics in its classical form i.e. application of linguistics to language teaching and researching. The present curriculum of Master of English Education (M.Ed.) has replaced the erstwhile course Directions and Issues in Applied Linguistics (Eng. 525) with Linguistics in Application (Eng. 525), the latter reads much narrower than the former. The course title shows that applied linguistics has not moved beyond its initial phase that emphasizes the use of principles, theories and insights from linguistics to diagnose and solve language teaching problems. Moreover, the curriculum of English Education has incorporated different branches of applied linguistics (in the sense of application of linguistics) through different courses such as Critical Discourse Analysis (Eng. 527), SLA Theories and Research (Eng. 518), ESL Research and Testing (Eng.538), ELT Pedagogy and Materials (Eng. 535), Language, Society and Power (Eng. 526), and Translation Studies (Eng. 547). Following the framework of English Education, the curriculum of Master of Nepali Education has also treated applied linguistics as a subject necessary for language teaching and learning. The course entitled Prayogik Bhasa Bigyan-ka Pramukh Chhetraha-ru (Nep. 528) (Main Areas of Applied Linguistics) incorporates discourse analysis, stylistics, lexicography, and translation studies as its major components. All the activities of language teaching, training and research are the application of linguistics to language education in one way or the other. However, we should not forget the fact that such an application is one of the several dimensions of applied linguistics. By limiting applied linguistics to language teaching, we are recognizing only its mediating role and disregarding the fact that it is an independent field with its own academic position and pursuit.

Applied linguistics activities in the Nepalese academia are lacking in the key markings of an academic discipline, which, according to Grabe, are "professional journals, professional associations, funding resources for research projects, [...] and a large number of individuals who see themselves as applied linguists" (2002, p. 11). We do not have any journal of applied linguistics so far. The applied linguistics issues such as literacy and ideology, language policy and language planning, language inequality, language and technology, translation and interpretation, among others, find their expression only in other language-related journals such as Nepalese Linguistics published by Linguistic Society of Nepal, Journal of NELTA (published by Nepal English Teachers' Association) and Nepalese Translation published by Society of Translators Nepal. Applied linguistics issues are discussed only peripherally in the conferences organized by these language-related professional organizations. There has not been a fully-fledged conference devoted 
exclusively to applied linguistics in Nepal. Nevertheless, some academic attempts merit special mention. One of them is a week-long conference entitled Institute on Lexicography organized by the then Royal Nepal Academy in 1995. Historically significant, the conference aimed "to introduce the principles of dictionary making to practicing lexicographers and language teachers, and also to present the state-of-the-art in lexicographical works going on in different languages of Nepal" (Yadava and Kansakar, 1998, p. 127). It was the academic effort to apply linguistic knowledge and methods to address lexicographical issues in Nepal. Likewise, the conference entitled Annual ELT and Applied Linguistics Conference (2018 and 2019) organized by Department of English Education, Tribhuvan University has played an instrumental role in establishing the interface between applied linguistics and second language teaching. The conference recognized ELT and applied linguistics of equal value for prospective ESL/EFL teachers. Despite this, the conference has kept applied linguistics under ELT not vise versa. This suggests that applied linguistics is yet to come of age to claim its position as an academic and professional field in Nepal. It is necessary to shift its traditional role as a consumer of knowledge to producer of knowledge in the Nepalese context.

It is time to reflect on the questions such as: Do we have scholarly discourses amongst the professionals engaged in various language issues in the country and do we try to address them? Do we raise public awareness about language-related issues? Do we conduct research activities and publish their findings with a view to informing the public about linguistic issues? Have we ever promoted the locus of applied linguistics in Nepalese academia or universities? Have we ever tried to bridge the gaps between applied linguistic theory and praxis? Have we contributed to the growth of applied linguistics as a discipline?

Nepal is characterized by lingua-cultural diversity and plurality. Being a multilingual nation, it has been facing a number of language implicated issues that are awaiting expert knowledge in mediating the solutions. The language problems we are faced with include the issues related to lexicography and translation, language planning and educational language planning, lingua-cultural identity, and many more. Nepalese English is one of such emerging areas of exploration that poses both challenges and opportunities for us. Such emerging issues have been partially addressed by linguistics and English education where applied linguistics has the subaltern position with its subservient role. We need to rescue applied linguistics from 
such a position with its traditional role and establish it as a fully-fledge academically sound area of inquiry. So far as our context is concerned, applied linguistics is mainly used to produce efficient second language teachers and language researchers. Now we need to produce human resources in Nepal that can claim themselves as applied linguists to address the language-related issues raised above.

Reflecting on the historical development, before the 1980s, applied linguistics in fact was not applied linguistics in proper but linguistics applied as it aimed at the application of linguistic findings to language teaching only. A lot of water has flowed under the bridge since the discipline emerged. Applied linguistics is said to be a mediating as well as theory-producing discipline today. It mediates between theory and practice; between academic enquiry and professional practice; between experience and expertise; between language-implicated issues and linguistics in order to address the most pressing and controversial contemporary language issues, including intercultural communication, political and commercial persuasion, impact of new technologies on language use, global diffusion of English and its impact on other languages, language in education, foreign language teaching and learning, and so on (Cook, 2003). Moreover, applied linguistics has also emerged as a discipline to produce knowledge. Nepalese academia seems oblivious to the recent developments in applied linguistics. Thus, there are sufficient grounds to claim that we are not doing applied linguistics but merely linguistics applied.

\section{Are we doing critical applied linguistics or hypocritical applied linguistics?}

The critical approach to the study of any discipline is the cry of the day. Identifying different modes of critical approach, Pennycook (2004, pp. 802-03) discusses four types of responsibilities that applied linguists are supposed to bear; and he argues that to escape these responsibilities is to fall into the trap of hypocrisy. According to Pennycook, applied linguists are supposed to bear:

a. Ethical responsibility: Applied linguistics is not a value-free discipline. Linguistic concerns and political concerns such as inequality, poverty, racism etc. cannot be divorced from each other. To divorce the study of language from such issues is to deny ethical responsibility.

b. Political responsibility: No principled intervention can take place in a politically and intellectually neutral space. This is the denial of its own politics. Pennycook labels it as liberal ostrichism in mainstream applied linguistics. 
c. Intellectual responsibility: No principled intervention is possible without awakening to multi-post realities of poststructuralism, postmodernism, postcolonialism etc. To deny this fact is what Pennycook calls denial of intellectual responsibility.

d. Social and cultural responsibility: Language related issues are emerging from various corners of society, and these diverse voices are to be respected duly and addressed within the broader framework of applied linguistics.

There is every likelihood that Nepalese linguistic and applied linguistic practices end up with these hypocrisies if we are not awakened to bear the aforementioned responsibilities.

\section{Conclusion}

As a fully-fledged discipline in action, applied linguistics is yet to come of age in Nepal. The discipline is yet to transcend its traditional role of supporting language-related areas only, and rise from the subservient position of being under linguistics and second language teaching in order to embrace the novel roles of generating its own theories and mediating sociopolitical issues where language is implicated. Apart from its traditional role of supporting language teaching, especially English language teaching, applied linguistics in Nepal should direct its attention to other languagerelated socio-political, academic and professional issues such as language planning, educational language planning, stylistics, translation practice, language and law, language and gender, language minorities, building technology-enhanced corpuses of Nepalese languages, etc. For this to happen, applied linguistics should be recognized and established as an independent field of teaching, training and researching in Nepalese academia so that we can have theoretically informed and contextually aware human resources who can proudly call themselves applied linguists. There is a dire need of such human resources to study the language-based problems/issues in relation to the diverse fields such as anthropology, sociology, history, education, technology, economics, and politics, and to meditate the problems for the benefit of society. Moreover, for this field to thrive academically and professionally in Nepal, it should have its own professional journal, professional association and funding resources.

\section{References}

Allwright, Dick. (1998). Applied linguistics. In K. Johnson and H. Johnson (Eds.), The encyclopedic dictionary of applied linguistics (pp.9-11). 
USA: Blackwell Publication.

Capra, Fritjof. (1976). The tao of physics. Flamingo: India.

Central Department of Linguistics. Welcome to central department of linguistics. Retrieved from https://cdltu.edu.np/

Cook, Gay. (2003). Applied linguistics. Oxford: Oxford University Press.

Corder, Stephen Pit. (1973). Introducing applied linguistics. England: Penguin.

Curriculum Development Centre. (2012). Issues and directions in applied linguistics. Tribhuvan University: Nepal.

Doren, Charles Van. (1991). A history of knowledge. New York: Ballantine Books.

Grabe, William. (2002). Applied linguistics: an emerging discipline for the twenty first century. In Kaplan, Robert. B. (Ed.) The Oxford handbook of applied linguistics (pp. 3-23). Oxford: Oxford University Press.

Kaplan, Robert. B. (2002). The Oxford handbook of applied linguistics. Oxford: Oxford University Press.

Lyons, John. (1971). Theoretical linguistics. Cambridge: Cambridge University Press.

Lyons, John. (2002). Languages and linguistics. Cambridge: Cambridge University Press.

Lyotard, Jean-Francois. (1984). The postmodern condition: A report on knowledge (Vol. 10). Minnesota: University of Minnesota Press.

Neubert, Albrecht. and Shreve, Gregory M. (1992). Translation as text. Kent Ohio: The Kent State University. Oxford University Press.

Office of the Dean. (2015). Master of Education: Semester course structure. Tribhuvan University: Kirtipur

Pennycook, Alastair. (2004). Critical applied linguistics. In Elder, C. and Davies, A. (Eds.), The handbook of applied linguistics (pp.784807). Blackwell: Australia.

Rajagopalan, K. (2004). The philosophy of applied linguistics. In Elder, C. and Davies, A. (eds.), The handbook of applied linguistics (pp. 397420). Blackwell: Australia.

Rampton, Ben. (1997). Retuning in applied linguistics. International Journal of Applied Linguistics, 7(1). pp. 3-25. 
Schmitt, Nobert and Celce-Murcia, Marianne. (2002). An overview of applied linguistics. In N. Schmitt. (Ed.) (2002), An introduction of applied linguistics (pp. 1-16). London: Hodder Education.

Seidlhofer, Barbara. (2003). Controversies in applied linguistics. Oxford: Oxford University Press.

Sridhar, N. (1993). What are applied linguistics? International Journal of Applied Linguistics, 3(1). Pp. 3-15.

Subedi, Abhi. (2007). Who speaks in linguistics? Recent Studies in Nepalese Linguistics. Proceedings of the $12^{\text {th }}$ Himalayan Languages Symposium and $27^{\text {th }}$ Annual Conference of Linguistic Society of Nepal, Nov. 26-28.

Tuladhar, Nirmal M. (1994). Presidential address of the Fourteenth Annual Conference of the Linguistic Society of Nepal, on November 26, 1993 at the CEDA Auditorium Tribhuvan University. Nepalese Lingusitics, 11. pp. 51-52.

Van Doren, Charles. (1991). A History of knowledge: Past, Present and future. Ballantin: USA.

Webster, Jonathan (Ed.). (2003). On language and linguistics. Continuum: London.

Widdowson, Henry. G. (2001). Coming to terms with reality: Applied linguistics in perspective. Applied linguistics for the 21st century, AILA Review, 14. pp. 2-17.

Williams, Raymond. (1977). Marxism and Literature. Oxford: Oxford University Press.

Yadava, Yogendra and Kansakar, Tej R. (Eds.) (1998). Lexicography in Nepal. Proceedings of the Institute on Lexicography, 1995. Kathmandu: Royal Nepal Academy. 